\title{
ISOLATION OF LEPTOSPIRA SEROVARS CANICOLA AND COPENHAGENI FROM CATTLE URINE IN THE STATE OF PARANÁ, BRAZIL
}

\author{
Francielle Gibson da Silva Zacarias ${ }^{1}$; Silvio Arruda Vasconcellos ${ }^{2}$; Eleine Kuroki Anzaii ${ }^{1}$; Nilson Giraldi²; \\ Julio Cesar de Freitas ${ }^{1}$; Rudy Hartskeerl ${ }^{3}$
}

\begin{abstract}
${ }^{1}$ Programa de Pós-graduação em Ciência Animal, Laboratório de Leptospirose Animal, Universidade Estadual de Londrina, Londrina, PR, Brasil; ${ }^{2}$ Programa de Pós-graduação em Epidemiologia Experimental e Aplicada às Zoonoses, Laboratório de Zoonoses Bacterianas, Faculdade de Medicina Veterinária e Zootecnia da Universidade de São Paulo, São Paulo, SP, Brasil; ${ }^{3}$ KIT Biomedical Research, Royal Tropical Institute - Leptospirosis Reference Center, Amsterdam, Netherlands.
\end{abstract}

Submitted: October 03, 2007; Returned to authors for corrections: March 17, 2008; Approved: November 02, 2008.

\begin{abstract}
In 2001, 698 urine samples were randomly collected from cattle at a slaughterhouse in the State of Paraná, Brazil. Direct examination using dark field microscopy was carried out immediately after collection. Five putative positive samples were cultured in modified EMJH medium, yielding two positive cultures (LO-14 and LO-10). Typing with monoclonal antibodies revealed that the two isolates were similar to Canicola (LO-14) and Copenhageni (LO-10). Microscopic agglutination test results show that Hardjo is the most common serovar in cattle in Brazil. Rats and dogs are the common maintenance hosts of serovars Copenhageni and Canicola. The excretion of highly pathogenic serovars such as Copenhageni and Canicola by cattle can represent an increasing risk for severe leptospirosis is large populations, mainly living in rural areas.
\end{abstract}

Key words: Leptospira, culture, leptospirosis, diagnosis, cattle

\section{INTRODUCTION}

Leptospirosis causes high economic losses form the cattle industry worldwide, mainly due to impaired reproductive performance (5). In Brazil, serological results using the microscopic agglutination test (MAT) have shown that cattle infection with leptospires is widespread $(12,16,20,23)$. Several other MAT-based survey studies in cattle have revealed various reactive serovars in different countries, however, serovar Hardjo was the most important throughout the world (8).

In rodents and dogs, dark field microscopy (DFM) is used for direct detection of leptospires in organic fluids like urine and blood. Yet, DFM is not recommended for use in cattle, because of its notorious low sensitivity and specificity (11). Furthermore, application of DFM on urine samples from cattle meets additional limitations due to the difficulty to collect urine samples and the need of a laboratory facility near the site of collection. A more reliable approach in this situation is bacterial culturing; however it is fastidious and mastered by a small number of laboratories.

Leptospira isolation from organic fluids and organs has been improved by the development of suitable culture media, antibiotic cocktails, and better sample handling and dilution techniques $(1,15)$. Today leptospires have been isolated from urine, kidney and uterus of chronically infected cattle throughout the world $(10,13,22)$. Although available serological, histological and molecular tests have more optimal diagnostic values, isolation is necessary for epidemiological and prophylactic studies of the disease. In Brazil, so far the following Leptospira serovars have been isolated from cattle; Pomona, Icterohaemorrhagiae, Hardjo, Georgia and two autochthonous serovars, Guaricura and Goiano (27).

However, considering that few isolation studies have been performed in cattle in Brazil, it is possible that some serovars may be restricted to specific geographical areas. Continuation of such studies is therefore of utmost importance. In this study

*Corresponding Author. Mailing address: Programa de Pós-graduação em Ciência Animal, Laboratório de Leptospirose Animal, Universidade Estadual de Londrina, Londrina, PR, Brasil. E-mail: francielleg@hotmail.com 
we present the results of a study in cattle in the state of Paraná, using a combination of DFM for initial screening and culturing followed by serological typing of isolates.

\section{MATERIAL AND METHODS}

\section{Collection of samples}

From April 2001 to December 2001, in cooperation with the Federal Food Inspection service, urine samples were collected from 698 male and female, healthy cattle, which were randomly selected during slaughter at an abattoir in the state of Paraná. Animals came from the northern and center-southern regions of the state of Paraná, Brazil.

Urine samples were obtained approximately ten minutes after slaughter. Approximately $3 \mathrm{~mL}$ were collected from each animal by direct bladder puncture on the slaughterhouse eviscerating table. After collection, urine samples were transferred to a location near the slaughter room, where they were examined by DFM, Olympus $^{\circledR}$ - Model Bx40 microscope, with $200 \mathrm{x}$ magnifications. Positive samples were used for culturing.

\section{Culture media}

Cultures were carried out in EMJH medium (3) and Tween $80 / 40 / \mathrm{LH}$ medium (7). The EMJH medium was modified by supplementation with $10 \%$ rabbit serum enriched with Lasparagine, sodium pyruvate, calcium chloride and magnesium chloride (3). This medium was prepared with and without a cocktail of antibiotics. This cocktail contained 5-fluorouracil (400 mg/L; Sigma $\left.{ }^{\circledR}-\mathrm{USA}\right)(15)$ and chloramphenicol (5 mg/L; Sigma $^{\circledR}$-USA), nalidíxic acid ( $50 \mathrm{mg} / \mathrm{L}$; Inlab $\left.{ }^{\circledR}-\mathrm{BR}\right)$, neomycine $(10$ $\mathrm{mg} / \mathrm{L} ;$ Sigma $^{\circledR}$-USA) and vancomycin $\left(10 \mathrm{mg} / \mathrm{L}\right.$; Acros ${ }^{\circledR}$-USA $)$ (25). Tween 80/40/LH medium was used without the addition of antibiotics.

\section{Leptospira isolation}

$0.5 \mathrm{~mL}$ aliquots of urine samples were inoculated into $5 \mathrm{~mL}$ of modified EMJH medium supplemented with antibiotics. The cultures were transported to the Leptospirosis Laboratory at Department of Veterinary Preventive Medicine (DMVP) - State University of Londrina (UEL), Paraná, Brazil, at room temperature ( 2 hours) and subsequently incubated at $28^{\circ} \mathrm{C}$ for 24 hours. After this period, $0.5 \mathrm{~mL}$ portions were subcultured in duplicate in $5 \mathrm{~mL}$ of the same medium but without antibiotics. The cultures (including the primary cultures) were examined weekly during 16 weeks by dark field microscopy (9).

After isolation, maintenance was carried out by repeated sub-culturing in modified EMJH without antibiotics and in Tween 80/40/LH.

\section{Typing of isolates}

The isolated strains were typing in the National Collaborating Centre for Reference and Research on
Leptospirosis (KIT Biomedical Research, Amsterdam, Netherlands) and WHO/FAO/OIE. To determine their presumptive serogroups, Leptospira isolates were subjected to MAT using a panel of 43 rabbit anti-Leptospira sera, representative of all pathogenic and saprophytic serogroups. Rabbit antisera (polyclonal) were prepared as described by Faine (11). MAT was carried out in a microtitre plate with serial two-fold dilutions of the rabbit antisera, starting with a serum dilution of 1:10, were mixed with equal volumes of viable leptospiral strains. After incubation at $30^{\circ} \mathrm{C}$ for 2 hours, the dilutions were investigated for agglutination by DFM. Titres represent the highest serum dilution, showing agglutination of $50 \%$ of the leptospiral cells in the suspension (28). Isolates were further typed at the serovar level by performing MAT with panels of monoclonal antibodies (mAbs) that characteristically agglutinate serovars belonging to a specific serogroup Canicola (F152C1, F152C2, F152C5, F152C7, F152C8, F152C10, F152C11, F152C13, F152C14, F152C17 and F152C18) and the Icterohaemorrhagiae group (F12C3, F20C3, F20C4 F52C1, F52C2, F70C4, F70C7, F70C13, F70C14, F70C20, F70C24, $\mathrm{F} 70 \mathrm{C} 26, \mathrm{~F} 82 \mathrm{C} 1, \mathrm{~F} 82 \mathrm{C} 2, \mathrm{~F} 82 \mathrm{C} 7, \mathrm{~F} 82 \mathrm{C} 8, \mathrm{~F} 89 \mathrm{C} 3$, and $\mathrm{F} 89 \mathrm{C} 12$ ) as described by Korver et al. (18).

\section{RESULTS}

Five of the 698 urine samples tested positive by DFM, containing cells with morphology and motility resembling leptospires. Four of these samples showed approximately two leptospirae cells per field ( $200 \mathrm{x})$, with normal motility and one presented about 20 cells per field, but with limited motility.

Leptospira isolation was successful in two urine samples, which scored positive by DFM: Londrina 14 (LO-14) (two cells with motility per field) and Londrina 10 (LO-10) (20 cells with limited motility per field). Both showed growth after 12 weeks of incubation. Other cultures were discarded as negative after 16 weeks of incubation.

Regarding maintenance, after weekly subculturing, the Tween $80 / 40 / \mathrm{LH}$ medium appeared to be more optimal than modified EMJH medium, which gradually reduced leptospirae growth rate.

To determine potential serogroups, the two isolates were initially agglutinated in the MAT against a panel of 43 rabbit anti-Leptospira reference sera. Markedly high titers were found with sera against serovar Canicola strain Hond Utrecht IV and serovar Copenhageni, strain M 20; and serovar Icterohaemorrhagiae, strain RGA for isolates LO-14 and LO-10, respectively (results not shown). This indicates that the isolates most probably belong to the corresponding serogroups: Canicola and Icterohaemorrhagiae. Subsequent typing was performed with panels of $\mathrm{mAbs}$ characteristically agglutinating the serovars in these two serogroups. Table 1, presents the agglutination profiles of the isolates compared with the 
Table 1. Reciprocal MAT titers against LO-14 and LO-10 and corresponding reference strains with panels of characteristically agglutinating mAbs.

\begin{tabular}{|c|c|c|c|c|c|}
\hline \multicolumn{3}{|c|}{ Serovar Canicola } & \multicolumn{3}{|c|}{ Serovar Copenhageni } \\
\hline $\mathrm{mAbs}$ & $\begin{array}{l}\text { Reciprocal titer } \\
\text { LO-14 }\end{array}$ & $\begin{array}{l}\text { Reciprocal titer reference } \\
\text { strain Hond Utrecht IV }\end{array}$ & $\mathrm{mAbs}$ & $\begin{array}{l}\text { Reciprocal titer } \\
\text { LO-10 }\end{array}$ & $\begin{array}{c}\text { Reciprocal titer } \\
\text { reference strainM } 20\end{array}$ \\
\hline $\mathrm{F} 152 \mathrm{Cl}$ & 640 & 5120 & $\mathrm{~F} 12 \mathrm{C} 3 *$ & 20480 & 20480 \\
\hline $\mathrm{F} 152 \mathrm{C} 2$ & $\geq 20480$ & 20480 & $\mathrm{~F} 20 \mathrm{C} 3$ & 10240 & 20480 \\
\hline F152C5 & $\geq 20480$ & 20480 & $\mathrm{~F} 20 \mathrm{C} 4$ & $>20480$ & 81920 \\
\hline $\mathrm{F} 152 \mathrm{C} 7$ & $\geq 20480$ & 20480 & $\mathrm{~F} 52 \mathrm{C} 1 *$ & 160 & 5120 \\
\hline $\mathrm{F} 152 \mathrm{C} 8$ & $\geq 20480$ & 10240 & $\mathrm{~F} 52 \mathrm{C} 2$ & - & - /low \\
\hline $\mathrm{F} 152 \mathrm{C} 10$ & $\geq 20480$ & 20480 & F70C4 & 1280 & 20480 \\
\hline $\mathrm{F} 152 \mathrm{C} 11$ & $>20480$ & 40960 & $\mathrm{~F} 70 \mathrm{C} 7 *$ & 1280 & 81920 \\
\hline $\mathrm{F} 152 \mathrm{C} 13$ & 640 & 5120 & $\mathrm{~F} 70 \mathrm{C} 13$ & 2560 & 10240 \\
\hline $\mathrm{F} 152 \mathrm{C} 14$ & 2560 & 5120 & F70C14* & - & - /low \\
\hline $\mathrm{F} 152 \mathrm{C} 17$ & 5120 & 2560 & F70C20 & 10240 & 20480 \\
\hline \multirow[t]{8}{*}{$\mathrm{F} 152 \mathrm{C} 18$} & 10240 & 5120 & F70C24* & 10240 & 40960 \\
\hline & & & F70C26 & 2560 & 2560 \\
\hline & & & $\mathrm{F} 82 \mathrm{C} 1$ & - & - \\
\hline & & & $\mathrm{F} 82 \mathrm{C} 2$ & - & - \\
\hline & & & $\mathrm{F} 82 \mathrm{C} 7$ & - & - \\
\hline & & & $\mathrm{F} 82 \mathrm{C} 8$ & - & - \\
\hline & & & F89C3 & 640 & 1280 \\
\hline & & & F89C12* & 1280 & 5120 \\
\hline
\end{tabular}

- No agglutination.

* Relevant mAbs for discrimination between serovars Icterohaemorrhagiae and Copenhageni. F12C3 specifically agglutinates both serovars Icterohaemorrhagiae and Copenhageni, F52C1 and F70C7 agglutinate all serovars of the Icterohaemorrhagiae group, F70C14 specifically agglutinates serovar Icterohaemorrhagiae, F70C24 specifically agglutinates serovar Copenhageni and F89C12 agglutinates all serovars in the Icterohaemorrhagiae group except serovar Icterohaemorrhagiae (18).

agglutination profiles of the most similar reference serovars from serogroups Canicola and Icterohaemorrhagiae.

A 4-fold titer difference in mAbs typing is acceptable. In the case of LO-14, agglutination titers of all $11 \mathrm{mAbs}$ meet the requirement when comparing to serovar Canicola, strain Hond Utrecht IV. Thus, LO-14 corresponds to serovar Canicola. Regarding LO-10, 15 of 18 agglutinations meet the criterion as compared to the reference serovar Copenhageni, strain M 20.

\section{DISCUSSION}

We collected 698 urine samples from cattle in a slaughterhouse. To reduce costs and workload, urine samples were first visually inspected by DFM for the presence of leptospires, accepting a certain degree of unreliability of this method. Positive samples were subsequently subjected to culturing. Five samples $(0.72 \%)$ were selected by DFM and two of them yielded positive cultures (success rate $40 \%$ ). A success rate of $40 \%$ in cultures from urine samples is quite acceptable, even for experienced laboratories. Therefore, we assume that the three negative cultures are due to failure of the isolation method. On the other hand, misjudgment in the unreliable DFM examination cannot be excluded. Our study did not allow repeated samples to compensate for intermittent shedding. Hence, the percentage of putative carriers determined by DFM is probably an underestimation of the actual percentage of carriers amongst cattle.

The use of EMJH medium with five antibiotics in the first 24 hours of incubation helped control of contaminating microorganisms. Culture media containing antibiotics could be used throughout the incubation period without altering the multiplication of Leptospira cells $(1,11)$. However, Schönberg (25) observed the harmful effect of antibiotics on leptospires growth after 48 hours of incubation.

EMJH medium has been successfully used for isolation and maintenance of leptospires $(8,19)$. However, in this study, the isolated strains could not be maintained in this medium. It was observed that from the first subculture, there was a gradual decrease in the number of Leptospira cells and in their motility. No more leptospires were detected in the subsequent subcultures. 
Only Tween 80/40LH medium was suitable for maintenance of the two leptospirae isolates. Ellis; Thiermann (10) and Leonard et al. (19) applied this medium with only 5-fluorouracil or other antibiotics and obtained better leptospirae growth and results for cultures of samples from infected cattle.

In this study, growth of the two leptospirae strains was only observed after 12 weeks of incubation. This seems long, yet it is not unusual (6) as leptospires grow very slowly with generation times in the log phase of 16 - 18 hours (9) and cultures become positive even after one year of incubation (unpublished result). Therefore an incubation time of 46 months is advocated (28).

The criterion of agglutinations for LO-10 is remarkably similar, but not identical to the reference serovar Copenhageni, and therefore, might represent a sub-type of Copenhageni. It is interesting to point out that two of the mAbs with discrepant results, F52C1 and F70C7, usually strongly agglutinate all serovars of the Icterohaemorrhagiae group. Possibly, differences in antigenic structure are responsible for discrepancies in $\mathrm{mAbs}$ agglutinations. Serovars Canicola and Copenhageni belong to species Leptospira interrogans sensu stricto (4). Consistently, molecular typing of the isolates in a separate study identified both as L. interrogans (2).

The typing of the Leptospira strains isolated as Canicola and Copenhageni differs from serological investigations done in Brazil, which in spite of reporting the occurrence of these serovars in various animals quote serovar Hardjo as the most frequent $(12,26)$. Until now, only serovars Georgia, Goiano, Guaricura, Hardjo, Icterohaemorrhagiae and Pomona have been isolated from cattle in Brazil (27). The isolation of Canicola from cattle is a new and unexpected finding, since dogs are worldwide recognized as maintenance hosts of this serovar. Apparent shedding of these highly virulent serovars poses a serious hazard, for both veterinary and public health. Nowadays, in Brazil, Copenhageni is the main serovar responsible for cases of urban leptospirosis in humans, it is associated with severe forms of leptospirosis such as Weil's syndrome and severe pulmonary hemorrhage syndrome, with a case fatality rate $>50 \%$ $(17,21,24)$. One might expect Canicola infections to occur in urban regions where (stray) dogs act as the main reservoir. Urban leptospirosis is associated with brown rats and, likely, dogs, and mainly affects populations living in slum areas. In contrast, leptospirosis acquired through contact with infected cattle is considered to be an occupational risk, affecting farmers and meat workers. It is therefore well conceivable that excretion of highly pathogenic serovars such as Copenhageni and Canicola by cattle represents an increasing risk for severe leptospirosis is large populations, mainly living in rural areas (14). Our finding that cattle may act as an infection source for serious, potentially fatal disease has enormous public health implications, requiring more research, surveillance and attention of veterinary and public health authorities.

\section{ACKNOWLEDGMENT}

We thank FAPESP- Fundação de Amparo à Pesquisa do Estado de São Paulo for partial financial support and CAPESCoordenação de Aperfeiçoamento de Pessoal de Nível Superior for the fellowship of Francielle Gibson da Silva Zacarias.

\section{RESUMO}

\section{Isolamento de leptospiras dos Sorovares Canicola e Copenhageni em amostras de urina de bovinos no estado do Paraná, Brasil}

No ano de 2001, 698 amostras de urina foram colhidas aleatoriamente, durante o abate em um frigorífico do Estado do Paraná, Brasil. O exame direto em microscópio de campo escuro foi realizado imediatamente após a colheita. As cinco amostras de urina positivas neste exame foram semeadas em meio EMJH modificado, sendo possível o crescimento de leptospiras em duas (LO-14 e LO-10). As estirpes isoladas foram tipificadas, por painel de anticorpos monoclonais, como mais similares ao perfil das amostras de referência dos sorovares Canicola (LO-14) e Copenhageni (LO-10). No Brasil, inquéritos sorológicos utilizando a prova de soroaglutinação microscópica mostram o predomínio de reações para o sorovar Hardjo em bovinos. Roedores e cães são os reservatórios mais comuns dos sorovares Copenhageni e Canicola, respectivamente. A eliminação dos sorovares Canicola e Copenhageni pela espécie bovina pode resultar em um aumento na ocorrência de casos graves de leptospirose humana, principalmente na população rural.

Palavras-chave: Leptospira, cultura, leptospirose, diagnóstico, bovino

\section{REFERENCES}

1. Adler, B.; Faine, S.; Christopher, W.L.; Chappel, R.J. (1986) Development of an improved selective medium for isolation of leptospires from clinical material. Vet. Microbiol., 12, 377-81.

2. Ahmed, N.; Devi, S.M.; Á Valverde, M. de los; Vijayachari, P.; Machang'u, R.S.; Ellis, W.A.; Hartskeerl, R.A. (2006). Multilocus sequence typing method for identification and genotypic classification of pathogenic Leptospira species. Annal. Clin. Microbiol. Microbial., 28 (5), (doi:10.1186/1476-0711-5-28).

3. Alves, C.J. (1995). Influência de fatores ambientais sobre a proporção de caprinos soro-reatores para leptospirose em cinco centros de criação do Estado da Paraiba, Brasil. São Paulo, 104 p. (ph.D. Thesis. Faculdade de Medicina Veterinária e Zootecnia. USP)

4. Brenner, D.J.; Kaufmann, A.F.; Sulzer, K.R.; Steigerwalt, A.G.; Rogers, F.C.; Weyant, R.S. (1999). Further determination of DNA relatedness between serogroups and serovars in the family Leptospiraceae with a proposal for Leptospira alexanderi sp. nov. and four new Leptospira genomospecies. Int. J. Syst. Bacteriol., 49, 839-858.

5. Dhaliwal, G.S.; Murray, R.D.; Ellis, W.A. (1996). Reproductive performance of dairy herds infected with Leptopira interrogans serovar hardjo relative to the year of diagnosis. Vet. Rec., 138, 272-276. 
6. Ellis, W.A. (1994). Leptospirosis as a cause of reproductive failure. Vet. Clin. Nor. Am.: Food Animal Practice., 10 (3), 463-479.

7. Ellis, W.A.; Montgomery, J.; Cassells, J.A. (1985). Dihydrostreptomycin treatment of bovine carriers of Leptospira interrogans serovar hardjo. Res. Vet. Sci., 39, 292-95.

8. Ellis, W.A.; O'brien, J.J.; Cassells, J.A. (1981). Role of cattle in maintenance of Leptospira interrogans serotype hardjo infection in Northern Ireland. Vet. Rec., 108, 555-557.

9. Ellis, W.A.; O’brien, J.J.; Neill, S.D.; Ferguson, H.W.; Banna, J. (1982). Bovine leptospirosis: Microbiological and serological findings in aborted fetuses. Vet. Rec., 110, 147-150.

10. Ellis, W.A.; Thiermann, A.B. (1986). Isolation of leptospires from the genital tracts of Iowa cows. Am. J. Vet. Res., 47 (8), 169-96.

11. Faine, S.; Adler, B.; Bolin, C.; Perolat, P. (1999). Leptospira and Leptospirosis. 2 ed. Medisci, Melbourne, Australia. 272p.

12. Fávero, A.C.M.; Pinheiro, S.R.; Vasconcellos, S.A.; Morais, Z.M.; Ferreira, F.; Ferreira Neto, J.S. (2001). Leptospirose bovina. Variantes sorológicas predominantes em colheitas efetuadas no período de 1984 a 1997 em rebanhos de 21 estados do Brasil. Arq. Inst. Biol., 68 (2), 29-35.

13. Feresu, S.B. (1992). Isolation of Leptospira interrogans from kidneys of Zimbabwe beef cattle. Vet. Rec.,130, 446-448.

14. Ganoza C.A.; Matthias M.A.; Collins-Richards D.; Brouwer K.C.; Cunnningham C.B.; Segura E.R.; Gilman R.H.; Gotuzzo E.; Vinetz J.M. (2006). Determining risk for severe leptospirosis by molecular analysis of environmental surface waters for pathogenic Leptospira. PLos Medicine, 1329-1340.

15. Heer, S.; Riley, A.E.; Neser, J.A.; Roux, D.; De Lange, J.F. (1982). Leptospira interrogans sorovar pomona associated with abortion in cattle: isolation methods and laboratory animal histopathology. Onderstepoort J. Vet. Res., 49, 57-62.

16. Homem, V.S.F.; Heinemann, M.B.; Moraes, Z.M.; Vianna, M.C.B.; Silva, J.C.R.; Sakamoto, S.M.; Pinheiro, S.R.; Veiga, J.B.; Lau, H.D.; Quanz, D.; Tourrand, F.F.; Ferreira, F.; Ferreira Neto, J.S. (2000). Leptospirose bovina em Uruará, PA, município da Amazônia Oriental. Arq. Inst. Biol., 67 (1), 1-8.

17. Ko, A.I.; Galvao Reis M.; Ribeiro Dourado C.M.; Johnson W.D.; Rilay L.W. (1999). Urban epidemic of severe leptospirosis in Brazil. Salvador Leptospirosis Study Group. Lancet, 354, 820-825.
18. Korver, H.; Kolk, A.H.J.; Vingerhoed, J.; Leeuwen, J van.; Terpstra, W.J. (1988). Clasiffication of the serovars of Icterohaemorrhagiae serogroup by monoclonal antibodies. Isr. J. Vet. Med., 44 (1), 15-18.

19. Leonard, F.C.; Quinn, P.J.; Ellis, W.A.; O'farrell, K. (1992). Duration of urinary excretion of leptospires by cattle natrally or experimentally infected with Leptospirra interrogans serovar hardjo. Vet. Rec., 7 , 435-39.

20. Lilenbaum, W. (1996). Atualização em leptospiroses bovinas. $R$. Bras. Med. Vet., v. 18 (1), 9-13.

21. McBride, A.J.; Athanazio, D.A.; Reis, M.G.; Ko, A.I. (2005). Leptospirosis, Curr. Opin. Infect. Dis., 18, 376-386.

22. Mclintock, C.S.; Mcgowan, M.R.; Corney B.G.; Colley, J.; Smythe, L.; Dohnt M.; Woodrow, M. (1993). Isolation of Leptospira interrogans serovars hardjo e zanoni ITom a dairy herd in north Queensland. Aust. Vet. J., 70 (10), 393-394.

23. Rodrigues, C.G.; Müller, E.E.; Freitas, J.C. (1999). Leptospirose bovina: sorologia na bacia leiteira da região de Londrina, Paraná, Brasil. Ciência Rural, 29 (2), 309-14.

24. Sakata, E.E.; Yasuda, P.H.; Romero, E.C.; Silva M.V.; Lomar, A.V. (1992). Sorovares de Leptosira interrogans isolados de casos de leptospirose humana em São Paulo, Brasil. Rev Inst. Med. Trop. São Paulo, 34 (3), 217-221.

25. Schõnberg, A. (1981). Studies on the effect of antibiotic substances on leptospiras and their cultivation from material with a high bacterial count. Zbl. Bakt. Hyg., 249, 400-06.

26. Vasconcellos, S.A. (2000). Leptospirose em animais domésticos e silvestres. Prevenção e controle. In: Estado da arte e prioridades para a pesquisa e desenvolvimento em leptospirose. Oficina de trabalho. Salvador, BA. Anais do evento comemorativo do centenário do Instituto Oswaldo Cruz e da Faculdade Oswaldo Cruz, Rio de Janeiro. Centro de informação científica e tecnológica/FIOCRUZ, 181-208.

27. Vasconcellos, S.A. (2005). Vacinas para a Leptospirose animal, situação atual e prespectivas: Revisão de sorovares de leptospiras isoladas no Brasil em animais silvestres e domésticos. XXIII Congresso Brasileiro de Microbiologia, Santos, São Paulo.

28. World Health Organization. (2003). Human leptospirosis; guidance for diagnosis, surveillance and control. Available at: http:// whqlibdoc.who.int/hq/2003/WHO_CDS_CSR_EPH_2002.23.pdf 